\title{
Implication of complex vertebral malformation and deficiency of uridine monophosphate synthase on molecular-based testing in the Iranian Holstein bulls population
}

\author{
A. R. Rezaee, M. R. Nassiry, B. Sadeghi ${ }^{\star}$, A. Shafagh Motlagh, M. Tahmoorespour and R. \\ Valizadeh
}

Department of Animal Science, Faculty of Agriculture, Ferdowsi University of Mashhad, Mashhad, Iran.

Accepted 7 April, 2009

\begin{abstract}
The aim of this study was to identify the deficiency of uridine monophosphate synthase (DUMPS) and the complex vertebral malformation (CVM) in Iranian Holstein bulls. A total of $\mathbf{1 4 4}$ blood samples were prepared of Holstein bulls in Abbas Abad Animal Breeding Center and Ferdowsi University of Mashhad's Dairy Farm in Khorasan state of Iran. Genomic PCR-RFLP protocol was performed to amplify the polymorphic region of the bovine uridine monophosphate synthase UMPS gene. Also, genomic PCR-SSCP method was performed for CVM to amplify the polymorphic region of the bovine solute carrier family 35 member 3 (SLC35A3) genes. The results of this study demonstrated that there was no carrier of DUMPS and CVM in Iranian bulls in these centers.
\end{abstract}

Key words: DUMPS, CVM, RFLP, SSCP, Iranian Holstein bulls.

\section{INTRODUCTION}

Elimination of animals and species affected by inherited defects is in the interest of all concerned with animal agriculture (Robinson and Shanks, 1990). Understanding the molecular basis of a genetic defect renders it possible to detect carriers directly at the DNA level and more important, early in the animal's life and even in embryonic cells (Harlizius et al., 1996). There are several autosomal recessive genetic diseases in cattle such as deficiency of uridine monophosphate synthase (Robinson et al., 1993) and complex vertebral malformation (Steffen, 2001).

The deficiency of uridine monophosphate synthase is a hereditary recessive disorder in Holstein cattle causing early embryo mortality (Kaminski et al., 2005). In mammalian cells, uridine monophosphate synthase (UMPS) is the enzyme responsible for converting orotic acid to uridine monophosphate (UMP), which is an essential com-

*Corresponding author: E-mail: bolbolbalal@yahoo.com, sadeghi.balal@stu-mail.um.ac.ir. Fax: +985118796845.

6078 Afr. J. Biotechnol. ponent of pyrimidine nucleotides. This enzyme actually has two enzymatic functions: orotic phosphoribosyl transferase (OPRTase) and orotidine monophosphate decarboxylase (OMPDCase), corres-ponding to the last two steps in pyrimidine synthesis (Patel et al., 2006). The mutation $(\mathrm{C} \rightarrow \mathrm{T})$ in a gene for UMPS at codon 405 from exon 5 (Patel et al., 2006) of bovine chromosome 1 (Harlizius et al., 1996) leads to a premature stop codon, which subsequently produces a functionally impaired enzyme (Schwenger et al., 1993). Carriers are phenoltypically normal, but have only half the normal activity of uridine monophosphate synthase. Also, during lactation, carriers excrete an elevated level of orotic acid in milk and urine (Robinson and Shanks 1990). Embryos homozygous for DUMPS do not survive to birth and usually die early in gestation. The embryos appear to be aborted or reabsorbed approximately 40 days after conception, leading to repeated breeding problems (Robinson et al., 1993; Lee et al., 2002).

Most of the DUMPS carriers identified in North America $(n=438)$ and Europe $(n=314)$ were offsprings of Happy 
Table 1. Locus-specific primers and reaction conditions

\begin{tabular}{|l|l|l|}
\hline \multicolumn{1}{|c|}{ Locus } & \multicolumn{1}{|c|}{ Reference } & \multicolumn{1}{c|}{ Primer Sequence (5'- 3') } \\
\hline UMPS & Patel et al. (2006) & $\begin{array}{l}\text { F: GCA AAT GGC TGA AGA ACA TTC TG } \\
\text { R: GCT TCT AAC TGA ACT CCT CGA GT }\end{array}$ \\
\hline SLC35A3 & Rusc et al. (2007) & $\begin{array}{l}\text { F: TCA GTG GCC CTC AGA TTC TC } \\
\text { R: CCA AGT TGA ATG TTT CTT ATC CA }\end{array}$ \\
\hline
\end{tabular}

Herd Beautician that, it was the fifth best U.S. Holstein bull in 1987 because of its production and other characteristics (Kaminski et al., 2005; Patel et al., 2006). Occurrence of mutation in the UMPS gene was reported in Argentina (Poli et al., 1996), Hungary (Fesus et al., 1999) and Taiwan (Lin et al., 2001). Against these reports, there was no carrier of DUMPS in Holstein and native cattles of Turkey (Akyuz et al., 2008), Polish Holstein breed (Kaminski et al., 2005) and Holstein Friesian (HF) and HF crossbred cattle in India (Patel et al., 2006).

The complex vertebral malformation (CVM) is a hereditary lethal syndrome in Holstein calves and is characterized by misshapen vertebrae in the cervical, thoracic and lumbar regions of the vertebral column, anomaly of sternum (Nagahata et al., 2002), abnormality of ribs (Revell et al., 2001), low body weight and lateral rotation of the fetlock joints (Duncan et al., 2001). Also, consideration of the heart reveals a right-sided hypertrophy and upper interventricular septal defect (Citek et al., 2004) and many CVM fetuses are aborted at gestation day 159 , while other CVM calves are pre-maturely born or usually stillborn (Agerholm et al., 2001; Nielsen et al., 2003). The molecular cause of CVM is a substitution of guanine by thymine $(G \rightarrow T)$ in a solute carrier family 35 member 3 gene (SLC35A3) at codon 559 from bovine chromosome 3 , encoding a UDP-N-acetylglucosamine transporter. This transversion results in the substitution of valine by phenylalanine at position 180 (Thomsen et al., 2006).

The main ancestor of cattle carrying this mutation was Carlin-M Ivanhoe Bell which was an elite breeding bull of Holstein-Friesian (HF) breed born in 1974 (Agerholm et al., 2004). At first, CVM was discovered in Danish Holstein calves in 2000 (Citek et al., 2004) and after that, the presence of CVM carriers was reported in some countries such as Sweden (Berglund et al., 2004), Denmark (Agerholm et al., 2004), Czech Republic (Citek et al., 2006) and Poland (Rusc et al., 2007).

Because Holstein semen is extensively used for crossbreeding programs with indigenous cattle, it has become necessary to screen all crossbred animals, especially artificial insemination (Al) bulls, to minimize the risk of spreading genetic diseases (Patel et al., 2006). Thus, the objective of the present study is to identify the carrier of DUMPS and CVM from Abbas Abad Animal Breeding Centers and Ferdowsi Univesity of Mashhad Dairy Farm in Khorasan state of Iran.

\section{MATERIALS AND METHODS}

Blood Samples were collected from 144 Holstein bulls in Abbas Abad Animal Breeding Center $(n=129)$ and Ferdowsi Univesity of Mashhad Dairy Farm in Khorasan state of Iran $(n=15)$ in 2008. Genomic DNA was extracted from $100 \mu$ of blood by guanidiumthiucianate silica gel method (Boom et al., 1990). PCR reactions were performed for amplification of polymorphic regions of the UMPS and SLC35A3 genes. The following primers were used for PCR (Table 1).

PCR was done in BiometraT- Personal Ver: 1.11 thermocycler by Gene pak PCR MasterMix Core Kit for amplification in a total volume of $20 \mu \mathrm{l}$. The PCR mix contained: $2 \mu \mathrm{l} \mathrm{PCR}$ buffer $10 \mathrm{X}, 1.5$ $\mathrm{mM} \mathrm{MgCl} 2,2 \mathrm{mM}$ dNTPs, $3 \mu \mathrm{l}$ mix of primers (10 pM from each

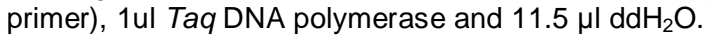

This solution was initially denatured at $94^{\circ} \mathrm{C}$ for 4 min followed by 35 cycles of denaturation $\left(94^{\circ} \mathrm{C}\right.$ for $\left.30 \mathrm{~s}\right)$, annealing $\left(61^{\circ} \mathrm{C}\right.$ for $\left.30 \mathrm{~s}\right)$ and elongation $\left(72^{\circ} \mathrm{C}\right.$ for $\left.30 \mathrm{~s}\right)$ and a final extention at $72^{\circ} \mathrm{C}$ for 10 min for uridine monophosphate synthase. Subsequently, this program was used for complex vertebral malformation with different annealing $\left(60^{\circ} \mathrm{C}\right.$ for $\left.30 \mathrm{~s}\right)$.

\section{RFLP and SSCP}

PCR products from the polymorphic region of UMPS gene (108 bp) were digested with avai restriction enzyme at $37^{\circ} \mathrm{C}$ for $18 \mathrm{~h}$. Digestion products were separated by electrophoresis on $4 \%$ agarose gel stained with ethidium bromide and M50 was used as ladder.

PCR product from SLC35A3 gene (177 bp) was analyzed by electrophoresis in $1.5 \%$ agarose gel. For SSCP analysis, $4 \mu \mathrm{L}$ of PCR product with $14 \mu \mathrm{L}$ of SSCP dye (95\% formamide, $0.05 \%$ bromphenol blue and $0.05 \%$ xylene cyanol) were denatured for 5 $\min$ at $95^{\circ} \mathrm{C}$ and immediately plunged into ice for $10 \mathrm{~min}$. The dilution was loaded onto a $10 \%$ polyacrylamide gel for SLC35A3 gene. The gel was run at a constant at $6^{\circ} \mathrm{C}$ for $6 \mathrm{~h}$ and was visualized with silver staining.

\section{RESULTS}

\section{DUMPS}

Agarose gel electrophoresis of PCR products from UMPS gene revealed same band in all lanes (108 bp). DNA ladder was M50 (Figure 1). Digestion products separated by electrophoresis showed that normal type and carrier was not detected (Figure 2). 


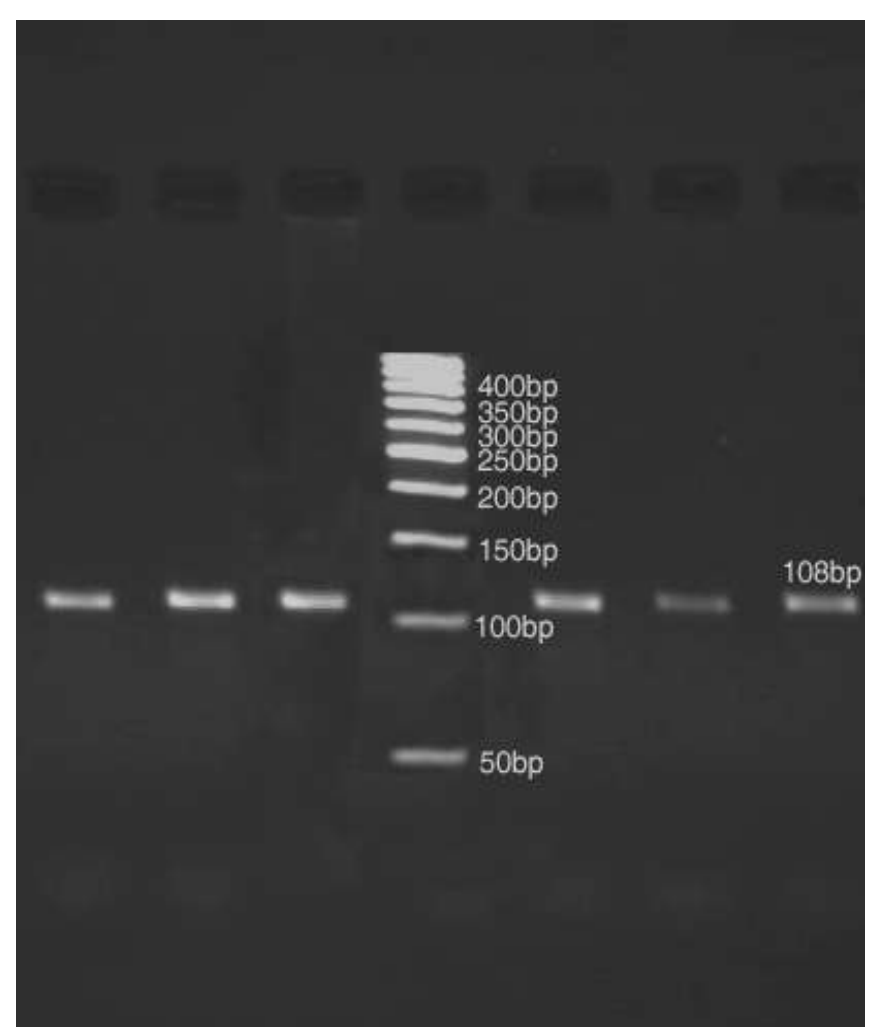

Figure 1. Agarose gel electrophoresis of PCR products from UMPS gene.

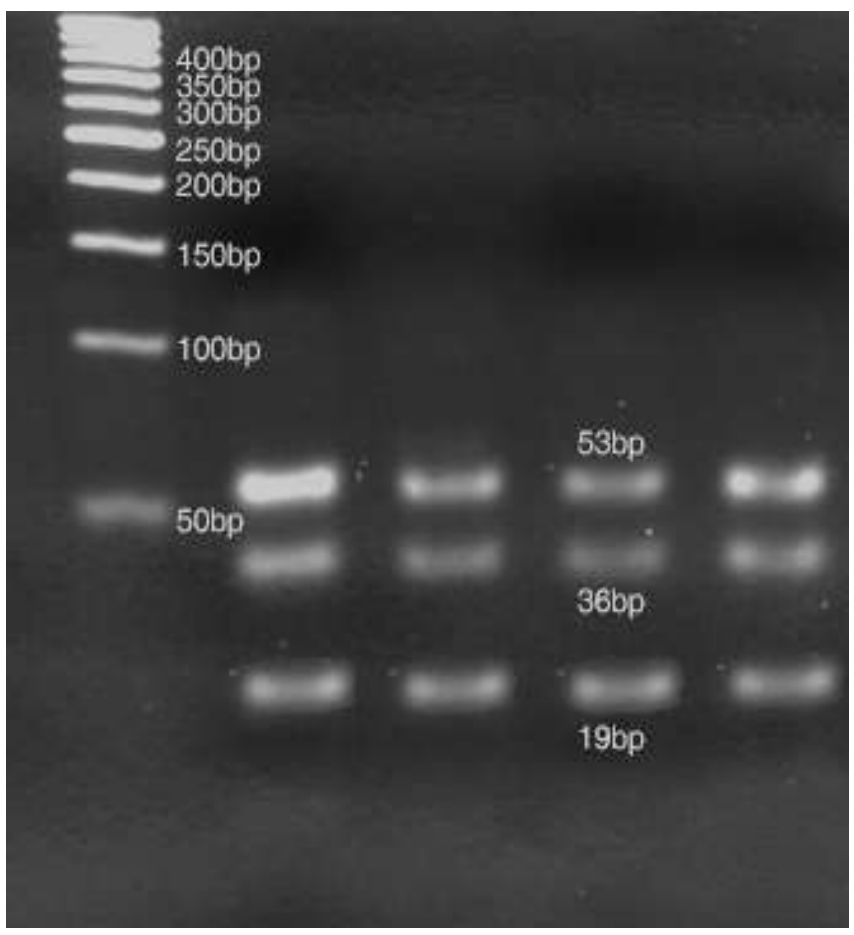

Figure 2. Agarose gel electrophoresis of digestion products from UMPS gene with Aval.

Rezaee et al

\section{CVM}

PCR product from the polymorphic region of SLC35A3 gene $177 \mathrm{bp}$ was analyzed by electrophoresis in 1.5\% agarose gel with ethidium bromide and M50 was used as ladder (Figure 3). SSCP analysis of SLC35A3 gene showed two bands for normal animal and there was no carrier of CVM (Figure 4).

\section{DISCUSSION}

Some studies were performed to prevent distribution of recessive alleles in dairy herds in Iran such as bovine leucocyte adhesion deficiency (BLAD) and citrolliemia. $B L A D$ is a hereditary disease in Holstein dairy cattle. To identify BLAD carriers in Holstein and Brown Swiss Al bulls in Iran, DNA samples from Holstein $(n=30)$ and Brown Swiss $(n=10)$ bulls from Abbas Abad Al center (Khorasan state, Iran) were analyzed. In this study, frequencies of BLAD carriers' genotypes in Holstein and Brown Swiss bulls were 3.33 and $0 \%$, respectively (Norouzy et al., 2005). Citrolliemia is another kind of hereditary disease in Holstein dairy cattle. For detection of citrolliemia, 26 blood and 4 semen samples were supplied from Iranian Holstein bulls used for Al from Abbas Abad Animal Breeding Center. Samples were tested by PCR-RFLP method. In this population, there was no bovine citrolliemia carrier (Nassiry et al., 2005).

In our study, we observed fragments of 19,36 and 53 bp that showed that there was no carrier of DUMPS in Iranian Holstein bulls of Abbas Abad Animal Breeding Center and Ferdowsi University of Mashhad Dairy Farm in Khorasan state of Iran. Similarly, Esmaelizad considered DUMPS in razi vaccine and Serum Research Institute in Iran. 130 samples of blood and sperm were supplied from Holstein bulls and the sperm bank in the Al center of Karaj Animal Breeding Center. In this study, all samples were free from DUMPS disease (Esmaelizad. 2003). Also, for detection of DUMPS in Holstein and native cattle of Turkey, 220 cattle consisting of 120 Turkish Holstein, 20 Swiss brown, 20 native black, 20 gray steppe, 20 South Anatolian red and 20 East Anatolian red breeds were studied. But, there was no positive results indicating the presence of DUMPS allele in any sample from the breeds and samples studied (Akyuz et al., 2008). In another study, 2,209 dairy cattle of the Polish Holstein breed have been screened by DNA test to identify carriers of these diseases (Kaminski et al., 2005). Similarly in India, a group of 642 animals, mainly Holstein Friesian (HF) (337) and HF crossbred (305) cattle were tested for DUMPS (Patel et al., 2006). In both of them, there was no DUMPS carrier. Against these results, mutations in the UMPS gene were identified in $1.79 \%$ bulls and $0.96 \%$ cows in Argentina (Poli et al., 1996). Fesus et al. (1999) found two HF carriers among 6080 Afr. J. Biotechnol. 


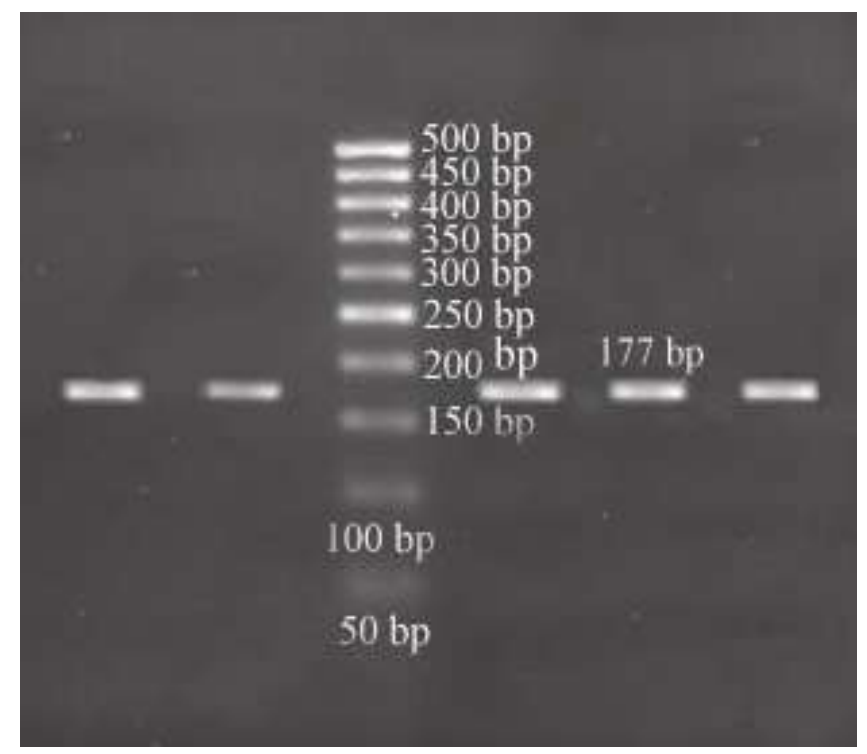

Figure 3. Agarose gel electrophoresis of PCR products from SLC35A3.

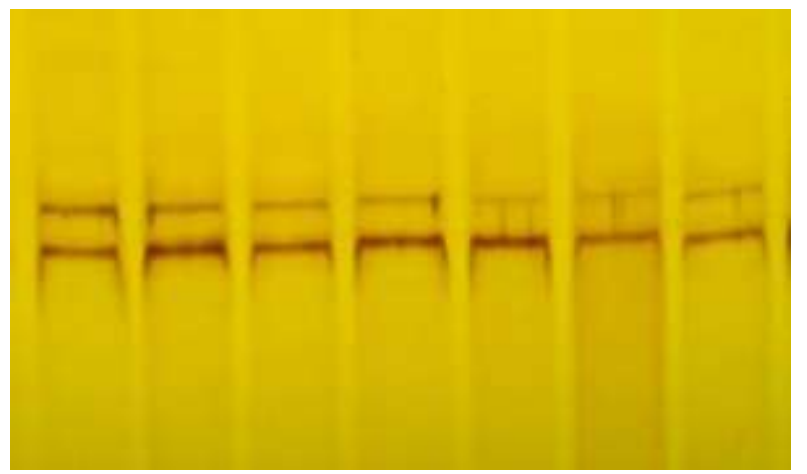

Figure 4. SSCP analysis of SLC35A3 gene. One SSCP pattern is visible.

314 Al bulls, 682 bull mothers and 155 young bulls in Hungary and in Taiwan, two carriers out of $1,468 \mathrm{HF}$ animals screened for DUMPS were reported (Lin et al., 2001).

In our research, carrier of CVM was not detected in Iranian Holstein bulls in these centers while, to investigate the congenital CVM in Holstein calves, two breeding studies were performed including 625 Danish cows. Out of the 625 cows in this study, 26 CVM affected calves were found (Agerholm et al., 2004). In another study, 111 females from the Holstein population in the Czech Republic were studied and 21 cases were found to be heterozygote (CVM carrier) while 90 cases were homozygous (non-carrier) (Citek et al., 2006). Also, to determine the carrier frequency of the CVM-determining mutation in a population of Polish Holstein-Friesian
(=Polish Black-and-White) cattle, 202 proven bulls and 403 unproven bulls (under evaluation for breeding value) were considered. Out of the 605 bulls examined, 150 heterozygotes were diagnosed (Rusc et al., 2007).

We used PCR-RFLP and PCR-SSCP to detect DUMPS and CVM alleles of Holstein bulls and showed that these methods are reliable and useful methods to extensively screen for these deficiency alleles and prevent economic losses. We did not observe any carrier for CVM and DUMPS. However, it is safe to say that the rate of infectious amount of Iranian endemic livestock is very low. Besides, omitting all the infected bulls in the past few years at these centers has led to a non-carrier rate. We can state that these diseases and their sources are from industrial livestock in USA and Europe and not from Iranian endemic breeds. Although no carrier has been observed in these centers, it does not follow that these diseases do not exist in Iranian endemic cattle.

\section{REFERENCES}

Agerholm JS, Bendixen C, Andersen O, Arnbjerg J (2001). Complex vertebral malformation in Holstein calves. J. Vet. Diagn. Invest. 13: 283-289.

Agerholm JS, Andersen O, Almskou MB, Bendixen C, Arnbjerg J, Aamand GP (2004). Evaluation of the inheritance of the complex vertebral malformation syndrome by breeding studies. Acta Vet. Scand. 45: 133-137

Akyuz B, Ertugrul O (2008). Detection of deficiency of Uridine Monophosphate Synthase (DUMPS) in Holstein and native cattle in Turkey. Ankara Univ. Vet. Fak. Derg. 55: 57-60.

Berglund B, Persson A, Stalhammar H (2004). Effects of complex vertebral malformation on fertility in Swedish holstein cattle. Acta Vet. Scand. 45: 161-165.

Boom R, Sol CJA, Salimans MMM, Jansen CJ, Wertheim-Van Dillen PME, Van Der Noordaa J (1990). Rapid and simple method for purification nucleic acid. J. Clin. Microbiol. 28: 495-503.

Citek J, Blahova B (2004). Recessive disorders - a serious health hazard. J. Appl. Biomed. 2: 187-194.

Citek J, Rehout V, Hajkova J, Pavkova J (2006). Monitoring of the genetic health of cattle in the Czech Republic. Vet. Med. 51: 333-339.

Duncan RB, Carrig CB, Agerholm JS, Bendixen C (2001). Complex vertebral malformation in a Holstein calf : report of a case in the USA. J. Vet. Diagn. Invest. 13: 333-336.

Esmaelizad M (2003). Molecular characterization of umps and asas genes and identification carriers of two genetic disorder Dumps and cytrollinaemia in Iran. Razi Vaccine and Serum Research Institute in Iran.

Fesus L, Anton I, Zsolnai A (1999). Marker assisted selection in livestock. DUMPS, Weaver-diseases and Citrullinaemia in cattle populations. Allatt.-es- Takarm. 48: 193-203.

Harlizius B, Schrober S, Tammen I, Simon D (1996). Isolation of the bovine uridine monophosphate synthase gene to identify the molecular basis of DUMPS in cattle. J. Anim. Breed. Genet. 133: 303-309.

Kaminski S, Grzybowski G, Prusak B, Rusc A (2005). No incidence of DUMPS carriers in Polish dairy cattle. J. Appl. Genet. 46(4): 395-397.

Lee YK, Chang KW, Nam IS, Chang WK, Tak TY, Kim KN, Lee KJ (2002). Studies on the detection of congenital genetic disorder in Holstein proven and candidate bulls. J. Anim. Sci. Technol. 44: 279288.

Lin DY, Huang YC, Chang HL, Liaw RB, Lee SC, Chen JC, Wu SC, Wu MC (2001). DNA typing of in- herited Deficiency of Uridine Monophosphate Synthase in dairy cattle and beef cattle. J. Chin. Soc. Anim. Sci. 30: 15-22. 
Nagahata $H$, Oota $H$, Nitanai A, Oikawa S, Higuchi $H$, Nakade $T$, Kurosawa T, Morita M, Ogawa H (2002). Complex Vertebral Malformation in a Stillborn Holstein Calf in Japan. J. Vet. Med. Sci. 64(12): 1107-1112.

Nassiry MR, Norouzy A, Eftekhari Shahroudi F, Javadmanesh A, Alishad M (2005). Investigation of two recessive disorders in breeder bulls of Abbas Abad animal breeding center. Iranian J. Biotechnol. 3(2): $125-128$

Nielsen US, Aamand GP, Andersen O, Bendixen C, Nielsen VH, Agerholm JS (2003). Effects of complex vertebral malformation on fertility traits in Holstein cattle. Livest Prod. Sci. 79: 233-238.

Norouzy A, Nassiry MR, Eftekhari Shahroudi F, Javadmanesh A, Mohammad Abadi M, Sulimova G (2005). Identification of Bovine Leucocyte Adhesion Deficiency (BLAD) Carriers in Holstein and Brown Swiss AI Bulls in Iran. Russian J. Genet. 41(12): 1409-1413.

Patel RK, Singh KM, Soni KJ, Chauhan JB, Sambasiva Rao KRS (2006). Lack of carriers of citrullinaemia and Dumps in Indian Holstein cattle. J. Appl. Genet. 47(3): 239-242.

Poli MA, Dewey R, Semorile L, Lozano ME, Albarino CG, Romanowski V, Grau O (1996). PCR screening for carriers of bovine leukocyte adhesion deficiency (BLAD) and uridine monophosphate synthase (DUMPS) in Argentine Holstein cattle. Zentralbl Vet. A43: 163-168.

Revell S (2001). Complex vertebral malformations in a Holstein calf in the UK. Vet. Rec. 149: 659-660.

Robinson J, Shanks RD (1990). Deficiency of uridine monophosphate synthase among Holstein cattle. C. Vet. 80: 119-122.
Robinson JL, Popp RG, Shanks RD, Oosterhof A, Weerkamp JH (1993). Testing for Deficiency of Uridine Monophosphate Synthase among Holstein- Friesian cattle of North America and Europe. Livest Prod. Sci. 36: 287-298.

Rusc A, Kaminski S (2007). Prevalence of complex vertebral malformation carriers among Polish Holstein-Friesian bulls. J. Appl. Genet. 48(3): 247-252.

Schwenger B, Schober S, Simon D (1993). DUMPS cattle carry a point mutation in the Uridine Monophosphate synthase gene. Genomics, 16: $241-244$

Steffen D (2001). CVM threatens Holstein herds. Vet. Pract. News: 36: p. 27.

Thomsen B, Horn P, Panitz F, Bendixen E, Petersen AH, Holm L (2006). A missense mutation in the bovine SLC35A3 gene, encoding a UDP-N- acetylglucosamine transporter, causes complex vertebral malformation. Genome Res. 16: 97-105. 